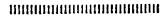 論 文

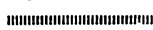 リアルタイム画像処理を用いた赤熱分塊 スラブの自動探傷装置
}

\author{
岩崎 全良*.中井 康秀*.西元 善郎* \\ 过 邦夫*2 $\cdot$ 広瀬 勇*3

\section{Automatic Surface Inspection System for Hot Rolled Slabs by Real Time Image Processing Method}

\author{
Masayoshi Iwasaki, Yasuhide NAKaI, Yoshiro Nishimoto, \\ Kunio TsujI, Isamu Hirose and Akira KoBAyashi
}

\begin{abstract}
Synopsis :
An automatic surface inspection system for grading hot slabs during the direct rolling process is described. The system, based on an optical method, employs CCD (Charge Coupled Device) line-scan cameras and real-time signal processors. CCDs can take hot radiant images of the moving slabs with high resolution. The signal processors, which use advanced image processing techniques, can perform the following functions. Firstly, the background level of the image of the slab can be correctly detected. Secondly, ill-defined signals caused by harmful defects can be discriminated with high signal-to-noise ratio. Thirdly, twodimensional patterns associated with defects can be recognized.

The effects obtained when the system is applied to operation are discussed. The ability of the system to detect dark and gray defects is comparable with that of human visual inspection. The system is now in successful operation in the direct rolling process.
\end{abstract}

\section{1. 緒言}

省エネルギー，工程の連続化を目的に実施されてきた 熱間直送压延 (HDR : Hot Direct Rolling), 熱片装入 (HCR : Hot Charged Rolling) では, 従来の半成品検 查に代わつて，赤熱状態の鋼片を探傷し，直送可否の判 定を下す必要がある. HDR, HCR が始まつた当初, 熱 間で使用できる適当な探傷装置がなかつたため, 操業オ ペレータまたは専門の検査員が，目視によつてその判断 をしていた. しかし, 検出性能や安全衛生上の問題, さ らには歩留り向上を目的とした熱間部分手入れの可能性 などの点からは，自動的に探傷することが望ましい，そ のため, これまでに種々の熱間探傷法が提案, 実施され ているが，筆者らは，ホットスカーフ後の分塊スラブを 対象に, HDR, HCR の直送可否判定用の赤熱表面自動 探傷装置を開発した，以下，その探傷方法と実操業への 適用結果について報告する.

\section{2. 熱間探傷法}

赤熱鋼材表面の探傷法としては，これまでに渦電流方
式及び光学方式が提案実施されている. 渦電流方式 1 ) 3) は鋼材に対向設置されたプローブコイルのインピーダン スが，鋼材表面の疵の有無により変化することを利用す る.この場合 1 個のコイルを用いて広い鋼材表面を走査 するか，多数個のコイルを固定配置して全面をカバーす るか，あるいは単一の周波数を用いるか，複数の周波数 を用いるかなどによつて種々の考案がなされている．渦 電流方式は微細な欠陷に対して優れた感度をもつている が，コイルを検査面に接近させる必要があり，プローブ の追従機構およびその耐熱性が構造上の問題となる. た磁気変態点付近の温度では透磁率の急激な変化が大き な信号変化をもたらし，探傷ができなくなるなどの問題 も含んでいる.

渦流探傷方式に対して光学方式は疪深さの情報を直接 得られない不利な点はあるが, 十分離れた位置から情報 が得られること, 対象材の寸法に余り依存せず，広い面 積を容易に走査できることが大きな特徵であり筆者らは 光学方式を採用した。

光学方式には4) 7)，赤熱鋼材の自発光を利用する放射 光方式と，照明光を用いてその反射光のみを選択的に捕

昭和 58 年 11 月 14 日受付 (Received Nov. 14, 1983)

* (株) 神戸製鋼所電子技術センター (Electronics Technology Center, Kobe Steel, Ltd., 53-3 Aza-Maruyama Gomo Nada-ku Kobe 657)

*2（株）神戸製鋼所技術開発本部 工博 (Technical Development Group, Kobe Steel, Ltd.)

*3 (株) 神戸製鋼所加古川製鉄所 (Kakogawa Works, Kobe Steel, Ltd.) 
える反射光方式とがある．前者には，赤熱鋼材の保有し ている熱による放射光を利用する受動的な方式と，外部 加熱により疵部での 発光状態の変化を捕光る能動的な 方式とがある。受光器には工業用テレビカメラが良く利 用されるがその他赤外線カメラや固体撮像器も用いられ る.移動中の鍽材を静止画像として撮影するため, ミラ 一を用いて視野を鋼材の移動に同期させたり，機械式シ ヤッタを用いて瞬時像を得るくふらがなされている。鋼 村表面像から㾋部を認識する方法では, 単にモ二タ上に 像を表示してオペレータの観察を容易にするものが大部 分であるが，陷部を抽出し，プリンタに出力するもの もある8).

Photo. 1 (a) は, 分塊スラプの赤熱画像の写真で, Photo. 1 (b) は, 同じ部分をストロボで照射し、フィ ルタによつて放射光を除いて撮影した反射光画像の写真 である. 反射光画像は, 冷間の表面と同様に見えるた め, 見やすく感じるが，久陥でない表面の微少な凹凸が 明暗となつて表現されるため, 湦淡情報から欠陥を自動 判定することはかなり困難である. Photo. 1 (b) の中 のへゲ疵や割れむ，人間はその陰影から表面の立体形状 を想像することによつて認識しているものと考えられ

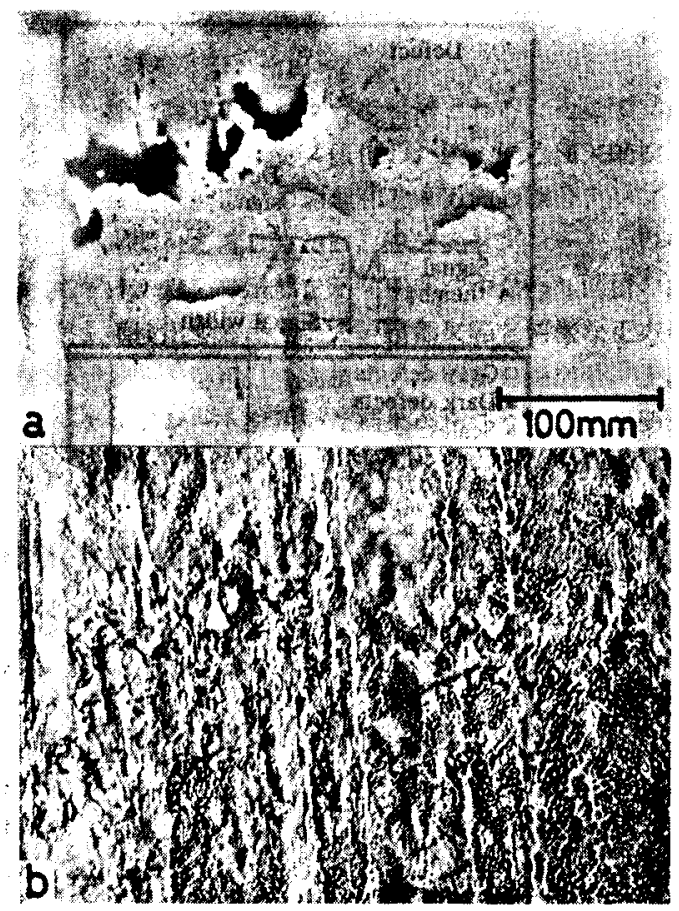

a) Surface image of radiated light

b) Surface image of reflected light

Photo. 1. Comparison of image of radiated light with that of reflected light.
る.このよらな人間の判断を機械でリアルタイム処理す ることは容易なことでない. 分塊スラブの場 合 Photo. 1（a）に示したように，明らかに赤熱画像の方が，S-N 比よく久陌検出ができそうである。筆者らはこのような 観点から, 放射光方式を選定し，この画像の中から症部 を自動的に検出する方法を考案した.

\section{3. 検出原理}

赤熱状態のスラブが自然冷却される時, 表面はほぼ均 一に冷却される. しかし Photo. 1(a) に示すように, 母材から剥離したへゲ瘷の部分では，母材からの熱エネ ルギーの供給が遮断されるため, 周用の正常な表面より 冷やされやすく黑く見える（放射光方式の探䂓を行う上 での分類として，これを暗部欠陥と呼ぶ．一方，母材に 深く食い込んだへダ疪や，き裂が表面に対し斜めになつ た横割れなどは，その遮断される熱エネルギーが少なく， より有害にもかかわらずあまり黒くならない(これを 灰色部欠陌と呼ぶ）。むた，開口部のある割れは，内部 の高温部が観察されるため，線状に明るく見える(これ を明部欠宿と呼ぶ）。これらの欠宿の部分を走查した時 得られる映像信号を，Fig. 1 亿模式的に示すが，これ らの映像信号の一次元的な処理のみでは欠陷を検出する ことは困難であり，二次元的な画像処理が必要となる. そこで Photo. 1(a) のような画像から症部の図形を抽 出することを目的として画像処理技術の各種の手法を検 討した.このよらな場合の画像処理では，画像の中の必 要な部分を明瞭にする强調の段階と, 個々の画像の存在 する特徵空間を明確にして，この中での閾值を定義し， 対象画像がこの閾値の内側にあるか，外側にあるかによ つて必要な画像を抽出する段階を綝り返し適用すること が行われる9).

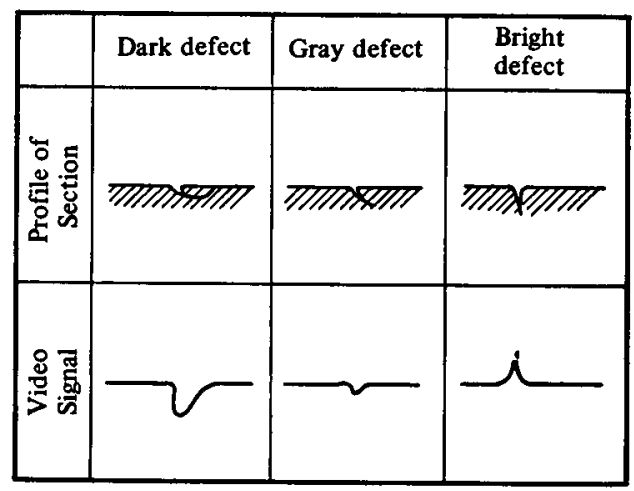

Fig. 1. Schematic profile of section and video signals of defects. 


\section{1 背景信号の除去（画像の強調）}

Photo. 1 (a) に示した画像の中で, 材面温度むらの 信号をまず除去し，対象とする画像を明瞭にする必要が ある. これに対する古典的な手法には 2 次元空間周波領 域の中での帯域フィルタを作用させる $\left.{ }^{10}\right)$ か, 平滑化した 画像を原画像から引き去る方法 ${ }^{11)}$ がある. 平滑化の方法 には局所平均法があり,これの変形に選択的局所平均 法 ${ }^{12)}$ がある. 筆者らは後者の手法を拡張して用いた.

画像上の画素の座標を $(i, j)$, 画像の明るさ（信号の 強度) を $f(i, j)$ として, 画像を $\Delta m \times \Delta n$ の長方形の区 画に区切り, その中での最大值をその区画の值とした画 像を求める. この最大值 $\hat{f}(i, j)$ は以下のように表現で きる.

$$
\begin{aligned}
\hat{f}(i, j) & =\operatorname{Max}\left\{f\left(i^{\prime}, j^{\prime}\right), f\left(i^{\prime}+1, j^{\prime}\right), \cdots,\right. \\
& f\left(i^{\prime}+\Delta m-1, j^{\prime}\right), \\
& f\left(i^{\prime}, j^{\prime}+1\right), f\left(i^{\prime}+1, j^{\prime}+1\right), \cdots \cdots \cdots, \\
& f\left(i^{\prime}, j^{\prime}+\Delta n-1\right), \cdots \cdots, \\
& \left.f\left(i^{\prime}+\Delta m-1, j^{\prime}+\Delta n-1\right)\right\} \cdots \cdots \cdots \cdots \cdots
\end{aligned}
$$

ただし， $i^{\prime}=\Delta m \cdot \operatorname{Int}(i / \Delta m), j^{\prime}=\Delta n \cdot \operatorname{Int}(j / \Delta n)$

その後, この画像に局所平均法を適用するが，その時 平均值に算入すべき值 $\hat{f}(i, j)$ がその前の平均值に比べ て大きく変化している場合には, 長手方向直前の区画の 值 $\hat{f}(i, j-\Delta n)$ を用いる. 比較対象となる平均值は, そ れ自身を求める際, $\hat{f}(i, j)$ を含んでいない長手方向至 近の平均值を用いる. この過程は局所平均の領域の大き さを $\left(2 M_{1}+1\right) \times\left(2 N_{1}+1\right)$ として，

$$
g(i, j)=\underset{k=-M_{1}, l=-N_{1}}{M_{1}} \underset{N_{1}}{N_{1}} \hat{f}(i+\Delta m \cdot k, j+\Delta n \cdot l) /
$$

$$
\left(2 M_{1}+1\right)\left(2 N_{1}+1\right)
$$

$$
\text { ただし }, \quad \hat{f}(i, j)>g\left\{i, j-\Delta n\left(N_{1}+1\right)\right\}+\varepsilon_{1}
$$

あるいは, $\hat{f}(i, j)<g\left\{i, j-\Delta n\left(N_{1}+1\right)\right\}-\varepsilon_{2}$ のとき $\hat{f}(i, j)=\hat{f}(i, j-\Delta n)$

と表すことができる. $\varepsilon_{1}, \varepsilon_{2}$ は変化の程度を決める定数 である.この平滑化画像を原画像から引くことにより， 画像の中の明部, 暗部が強調された画像 $h(i, j)=f(i$, $j)-g(i, j)$ が得られる.

\section{2 画像の抽出 ( 2 值化)}

$3 \cdot 2 \cdot 1$ 暗部欠陷の検出

$h(i, j)$ 上の暗黒斑は比較的面積のあるへゲ疵による ものに 2 次スケールによる小面積のものが混在してい る. そこでまず $h_{\mathrm{DO}}$ を閾值として $h(i, j)$ を 2 值化し た画像 $h_{\mathrm{D}}(i, j)$ を作り, $h_{\mathrm{D}}(i, j)$ に対して $\mathbf{M}_{\mathbf{2}} \times \mathbf{M}_{\mathbf{2}}$ 画素のテンプレートを用いた画像縮小法を 2 回適用して 小斑点を消去し必要な大きさの暗黒部を抽出して暗部欠
陥とする.すなわち 2 值化画像 $h_{\mathrm{D}}(i, j)$ に対して定数 $K_{1}, K_{2}$ を定め,

$$
\begin{aligned}
& \left.\underset{m=i}{i+M_{2}-1} \sum_{n=j}^{j+M_{2}-1} h_{\mathrm{D}}(m, n) \geqq K_{1}\right\} \\
& \text { のとき } h_{\mathrm{D}}{ }^{\prime}(i, j)=\left\{\begin{array}{l}
1 \\
0
\end{array}\right. \\
& \text { さらに } \left.\underset{m=i}{i+M_{n=j}-1} \sum_{n=j}^{j+M_{2}-1} h_{\mathrm{D}^{\prime}}(m, n) \underset{i}{\gtrless} K_{2}\right\} \\
& \text { のとき } h_{\mathrm{D}}{ }^{\prime \prime}(i, j)=\left\{\begin{array}{l}
1 \\
0
\end{array}\right.
\end{aligned}
$$

として暗部欠陥のみの画像 $h_{\mathrm{D}}{ }^{\prime \prime}(i, j)$ が得られる.

\section{$3 \cdot 2 \cdot 2$ 灰色部欠陥の検出}

Fig. 1 （a）に示したよらに灰色部欠陥は，信号振幅 が小さいため単純な閾值処理では抽出困難であるが，信 号の幅と振幅を 2 つのハラメータとする特徵空間の中で は，Fig. 2 に示すように分離されている. そこで $i_{1}<$ $i \leq i_{2}$ において $|h(i, j)|>h_{\mathrm{GO}}$ (間值) が成りたつと き $W=i_{2}-i_{1}, \quad H=\operatorname{Max}\{|h(i, j)|\} ; i=i_{1}+1 \sim i_{2}$ と 拈いて， $(H, W) E G$ (ただし $G$ は Fig. 2 の 印の領 域)ならば $h_{\mathrm{G}}(i, j)=1$ ， それ以外ならば $h_{\mathrm{G}}(i, j)=0$ として $h(i, j)$ を 2 值化する. しかし，この結果は，微 少なスケールによるノイズを含む可能性がある，そこで

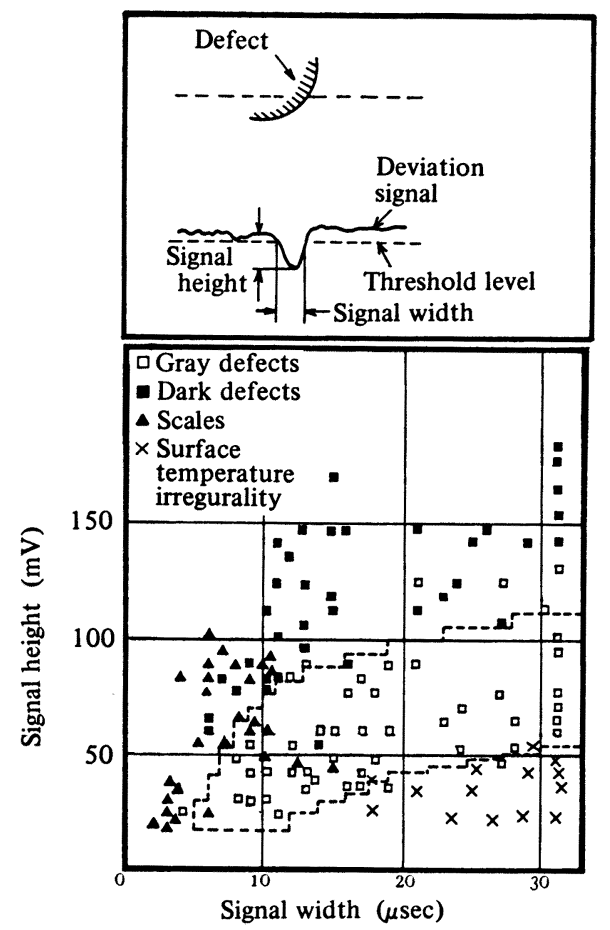

Fig. 2. Distribution of width and height of subsiding signal portions in deviation signals. 
対象とする欠陷画像に一定以上の平面的つながりがある といら特徵を利用して，この欠陥を抽出する．具体的に は，まずつながり方向のあいまいさを補い情報量を圧縮 するため $\mathrm{M}_{3} \times \mathrm{M}_{3}$ の区画ごとの論理和をとつた後， 4 方向の線分テンプレートとの相関を調べる.すなわち,

$$
\begin{aligned}
& h_{\mathrm{G}}^{\prime}(i, j)=h_{\mathrm{G}}\left(i^{\prime}, j^{\prime}\right) V h_{\mathrm{G}}\left(i^{\prime}+1, j^{\prime}\right) V . \\
& V h_{\mathrm{G}}\left(i^{\prime}+\Delta m-1, j^{\prime}\right) \\
& V h_{\mathrm{G}}\left(i^{\prime}, j^{\prime}+1\right) V h_{\mathrm{G}}\left(i^{\prime}+1, j^{\prime}+1\right) V \cdots \\
& \quad \ldots \ldots \ldots V h_{\mathrm{G}}\left(i^{\prime}+\Delta m-1, j^{\prime}+\Delta n-1\right)
\end{aligned}
$$

ただし， $i^{\prime}=\Delta m \cdot \operatorname{Int}(i / \Delta m), j^{\prime}=\Delta n \cdot \operatorname{Int}(j / \Delta n)$,

$$
V: \text { 理論和として, }
$$

$$
\begin{aligned}
& \sum_{l=-L_{0}}^{L_{0}} h_{\mathrm{G}}^{\prime}\left(i+M_{3} \cdot l, j\right)>L_{1}, \\
& \sum_{l=-L_{0}}^{L_{0}} h_{\mathrm{G}}{ }^{\prime}\left(i, j+M_{3} \cdot l\right)>L_{2} \\
& \sum_{l=-L_{0}}^{L_{0}} h_{\mathrm{G}}\left(i+M_{3} \cdot l, j+M_{3} \cdot l\right)>L_{3},
\end{aligned}
$$

$$
\sum_{l=-L_{0}}^{L_{0}} h_{\mathrm{G}}^{\prime}\left(i+M_{\mathbf{3}} \cdot l, j-M_{3} \cdot l\right)>L_{\mathbf{4}}
$$

ただし $2 L_{0}+1$ はテンプレートの大きさ, $L_{1}, L_{2}, L_{3}, L_{4}$ は定数.

のいずれかが成り立つたときのみ $h_{\mathrm{G}}{ }^{\prime \prime}(i, j)=1$ として, 灰色部欠陷を抽出した画像 $h^{\prime \prime}{ }_{\mathrm{G}}(i, j)$ を得る.

\section{$3 \cdot 2 \cdot 3$ 明部欠陷の検出}

明部欠陥は線状の明部として観察される. そこで $h_{\mathrm{BO}}$ を閾値として $h(i, j)$ を 2 值化した後, 灰色部欠陷検出 と同様に一定区画ごとの論理和と 4 方向の線分テンプレ ートとの相関をとる. しかし, 線分テンプレートとの相 関のみでは，材面の凹部を示す明部，すなわち面積のあ る明部を過検出する。そこで，暗部欠陥と同様な正方形 のテンプレートを用いて面積のある明部を抽出し，上記 線分のテンプレートを用いた結果からこれを除いて明部 欠陷を抽出する.

以上, 各種の処理におけるテンプレートの大きさや定 数は, 実際の画像を用いてシミュレーションした結果決 定した.

\section{4. 探 倡}

本探傷装置は，赤熱スラブの画像をとらえるセンサ， 前述の原理に基ついて欠陷を検出する画像処理装置, HDR, HCR における直送可否を判定する計算機からな る. 以下に, 七ンサの選定法, 画像処理装置の具体的構 成, 直送可否判定法について述べる.

\section{1 センサ}

センサを選定する場合, 温度分解能および空間分解能
についての検討を要する. 温度分解能は, 対象物体の放 射エネルギーとそのスペクトルおよびセンサの感度, 分 光特性, ダイナミックレンジによつてきまる. 今, 対象 とする $1000^{\circ} \mathrm{C}$ 付近のスラブを黒体と仮定し, 波長 0 ～ $\lambda_{\max }$ の一様な分光感度をもつセンサでその放射光物体 を見たとすると，センサに入射するエネルギーEは，

$$
E \fallingdotseq \frac{R}{4 F^{2}} \int_{0}^{\lambda_{\max }} \frac{C_{1}}{\lambda^{5}\left(\exp \left\{C_{2} / \lambda T\right\}-1\right)} d \lambda
$$

ただし， $C_{1}=3.74 \times 10^{4}\left(\mathrm{~W} \cdot \mu \mathrm{m}^{5} / \mathrm{cm}^{2} \cdot \mu \mathrm{m}\right), C_{2}=1.44 \times$ $10^{4}\left(\mu \mathrm{m} \cdot d_{\mathrm{eg}}\right), R:$ レンズの透過率, $F:$ レンズ の $\mathrm{F}$ ナンバ, $T:$ 対象物体の温度

となる. $F=4 \quad R=0.6$ として上式をグラフに書くと Fig. 3 のようになり, 絶対的な感度さえあれば，短波 長の分光感度のセンサを用いるほうが，温度変化に対す る出力変化が大きくなることがわかる. 空間分解能は, レンズの焦点距離を変えることによつて, 任意に選ぶこ とができるが，七ンサ 1 台あたりの視野を大きくし，空 間分解能を上げるには, 高分解能の画像センサを使ら以 外にない。また移動物体を撮像すると移動方向にぼけを 生じる. 例えば, 蓄積型面走査である工業用テレビカメ ラをとのまま使用すると, 約 $17 \mathrm{~ms}$ の間物体が移動する 距離だけぼけが生じ, 移動方向の空間分解能が低下す る. したがつて, 移動物体の撮像には非蓄積型か線走査 の画像センサが望ましい.

対象物体が約 $1000^{\circ} \mathrm{C}$ のとき, Fig. 2 において縦軸 の $10 \mathrm{mV}$ は約 $5^{\circ} \mathrm{C}$ の温度変化に相当して扣り, 前述の 原理を用いて直径数 $\mathrm{mm}$ 以上の久陥を検出するには, 約 $1^{\circ} \mathrm{C}$ の温度分解能と約 $1 \mathrm{~mm}$ の空間分解能が必要と 考えられる. そこで, 上記検討の結果 1 次元の GCD (Charge Coupled Device) イメージセンサカメラを採

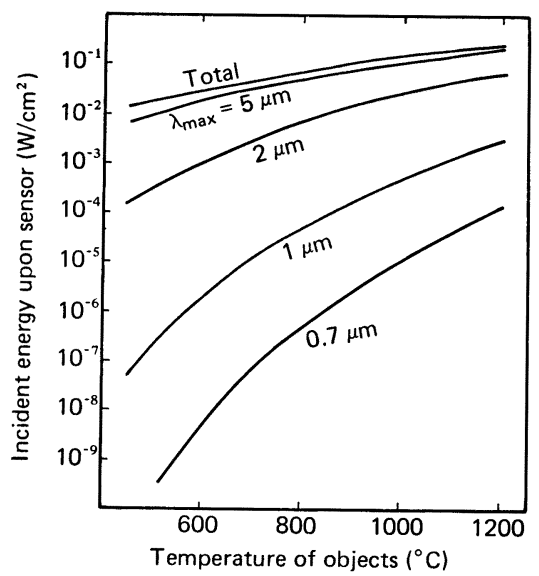

Fig. 3. Incident energy upon sensor. 
Table 1. Gharacteristics of GGD cameras.

\begin{tabular}{ll}
\hline Number of elements & 2048 \\
Scan cycle & $2.78 \mathrm{~ms}$ \\
Clock & $1 \mathrm{MHz}$ \\
Lens & f $35 \mathrm{~mm}, \mathrm{~F} 2$ \\
Range of vision & about $2 \mathrm{~m}$ \\
Noise equivalent temperature difference & about $1^{\circ} \mathrm{C}\left(\right.$ at $\left.1000^{\circ} \mathrm{C}\right)$ \\
Resolving power & about $1 \mathrm{~mm} \times 1 \mathrm{~mm}$ \\
\hline
\end{tabular}

用した. Table 1 にその仕様を示す.

\section{$4 \cdot 2$ 画像処理装置}

$1 \mathrm{~mm}^{2}$ の空間分解能で撮像すると, 例えば幅 $1.5 \mathrm{~m}$, 厚さ $200 \mathrm{~mm}$, 長さ $15 \mathrm{~m}$ のスラブを $30 \mathrm{~m} / \mathrm{min}$ の速 度で搬送する場合, 上下両側面で $1 \mathrm{~s}$ 間に $(1500+200)$ $\times 2 \times 500$ 画素の画像が得られ, lbyte/画素とすると, $1.7 \mathrm{Mbyte} / \mathrm{s}$, スラブ 1 枚で約 50 Mbyte の情報を処理 する必要がある．現状でこれだけの情報量を計算機でリ アルタイムに処理することは困難である. そこで検出原 理に記した各種の処理を専用ハードウェアで高速に行 い，得られた疪データの収集・表示および専用ハードウ ェアのパラメータ管理に計算機を利用した。

Fig. 4 に背景信号の除去回路のブロック図を示す. 一定区画ごとのピーク值を定めた後これの縦横の移動平 均を Slide averager によつて求め背景信号とする. そ の際その時点の背景信号に対して新しい映像信号が大き

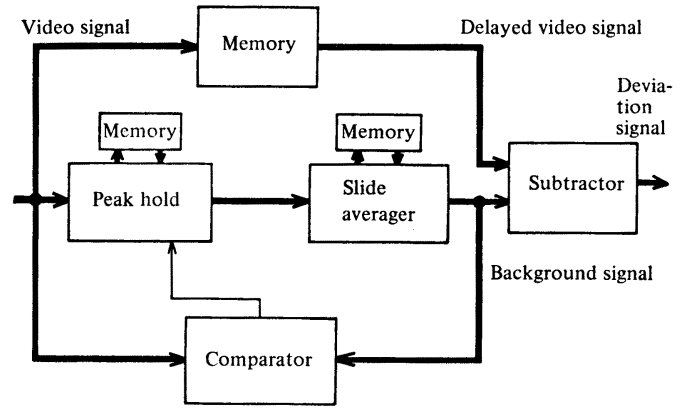

Fig. 4. Block diagram of background detector.

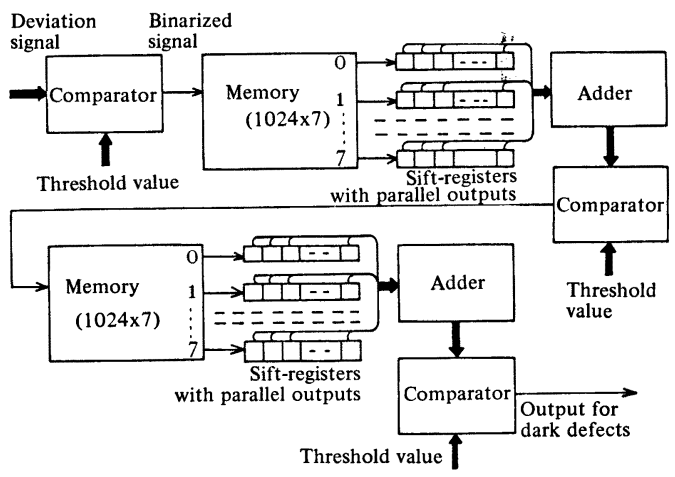

Fig. 5. Block diagram of dark defects detector.

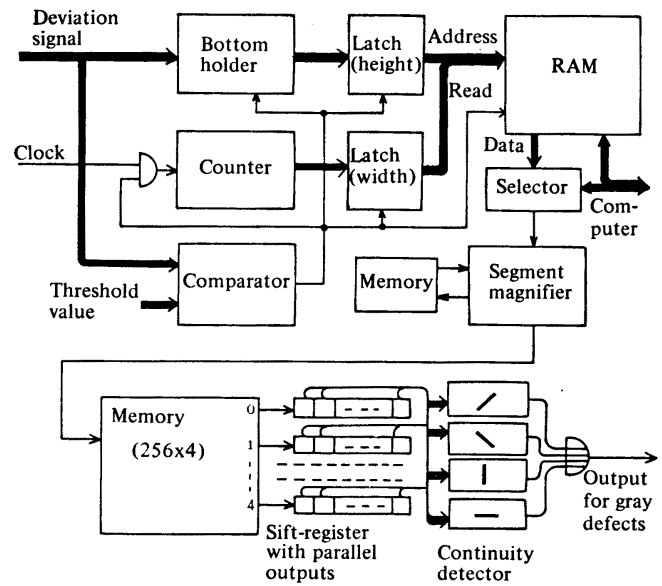

Fig. 6. Block diagram of gray defects detector.

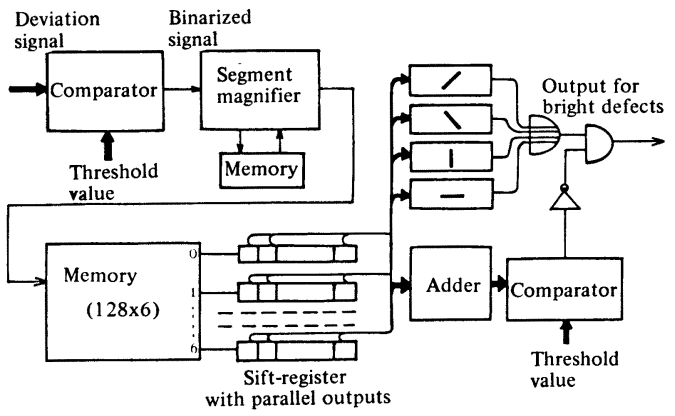

Fig. 7. Block diagram of bright defects detector.

な変化をしているか否かを Comparator によつて判断 し，大きい場合は長手方向の前回のピーク值を Memory から読み出し今回のピーク值として用いる.

Fig. 5 は暗部欠竹検出回路のブロック図で, 暗部の 2 值化を Comparator で行つた後映像信号 7 走査分の メモリとパラレルアウトシフトレジスタと加算器を用い て $8 \times 8$ 画素のテンプレートマッチングを 2 回行つて出 力を得る. Fig. 6 は扊色部欠陥検出回路のブロック図 である. RAM には Fig. 2 に示した $\square$ 印の領域を記憶 している.これに信号の幅と振幅をアドレスとして入力 し灰色部抽出をした後, 暗部欠陥検出回路と同様な回路 でテンプレートマッチングを行い，つながり判別を行 5. Fig. 7 の明部欠陥検出回路の場合も同様な方式を 採用している.

それぞれの欠陷検出回路で検出された結果は，スラブ

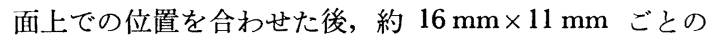
欠陥の有無を表すデータに変換される. その際同じ位置 に 2 種以上の欠陥が検出された場合, 経験により次のよ らなデータの変更を行つている. 
暗部欠陥と他の欠陥が共存した場合 $\rightarrow$ 暗部欠陥 明部欠宿と灰色部欠宿のみが共存した場合 $\rightarrow$ 明部欠宿

\section{3 直送可否判定}

HDR, HCR の直送可否を自動判定する際, 久陷の種 類, 個数, 位置, 密集の程度, さらにはスラブの鋼種や 用途などを考虑する必要がある，そこで，専用ハードウ ェアで検出した欠陥を種類別に一定区画ごとの個数とし て扱い，計算機を用いて各面の評価値

$$
F(s)=\underset{f, I, J}{\sum} g_{\mathrm{s}, \mathrm{r}, \mathrm{p}} \cdot d(N) \cdot N(s, f, I, J)
$$

ただし， $N(s, f, I, J)$ : 探傷面 (s) の区画位置 $(I, J)$ に扣ける種類 $(f)$ の欠陥個数

$g_{\mathrm{s}, \mathrm{f}, \mathrm{p}}$ : 探傷面 $(s)$, 種類 $(f)$, 位置区分 $(p(I$, J)）に抢ける重みつけけ係数

$d(N)$ : 密集の程度 $(N)$ によって変兄る俰数 を計算し，いずれかの面の評価値があらかじめきめた基 淮值を越えた場合に直送不可とした。なお，各係数と基 準值は，対象の鋼種別，用途別に定めた。

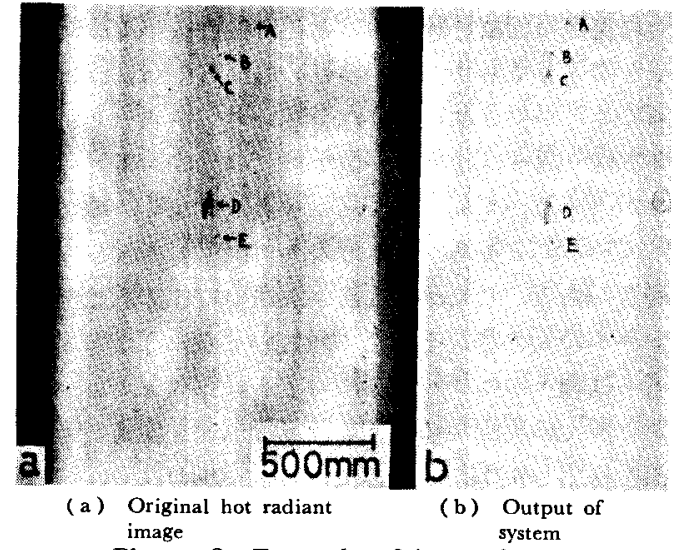

Photo. 2. Example of inspection.

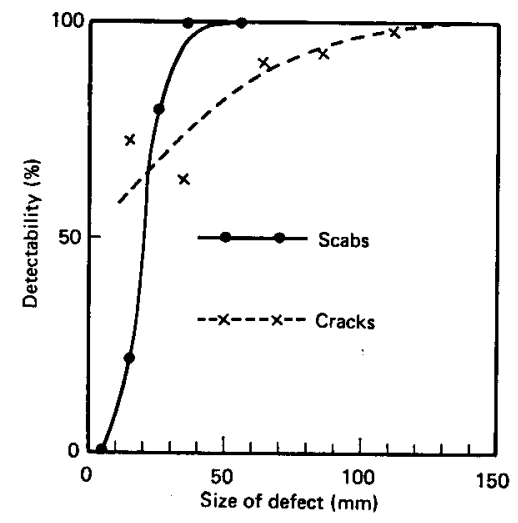

Fig. 8. Detectability for scabs and cracks.

\section{5. 検 出 性 能}

Photo. 2 K検出結果の一例を示す. 大きないゲ定

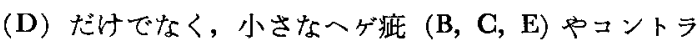
ストの低い横割れ（A）も精度よく検出している.

実際の自然欠宿に対する本装置の検出性能を調べるた め，探賃後のスラブを冷却した後目視検查を行い探傷装 置の抽出結果との対応をとつた．対象としたものは $\phi 5$ $\mathrm{mm}$ 以上の久陷約 400 個である.すべての疵をへゲ疪 と割れに分類し，大きさに対する検出率を Fig. 8 に示 す. 一ゲ疪については， $\phi 30 \mathrm{~mm}$ で注は $100 \%$, 割れに ついては $50 \mathrm{~mm}$ の長さで約 $80 \%$ 検出することがわか つた.この結果は, 同時に行つた熱間目視検查の性能と ほぼ同程度であつた．また，陷の種類の認識性能にっ いては，へダ疪は暗部欠陥または灰色部欠陥，割れは灭 色部欠陥または明部欠宿として検出されており，灰色部 欠宿と明部欠宿を重欠陥とすると，へダ疵の約 $20 \%$ が 重欠陥として認識されることがわからた。

\section{6. 実操業への適用と効果}

本装置は，HDR，HGR におけるスラブ直送可否判定 用として，'82 年 2 月から本移動に入り，ほぼ $100 \%$ 適 用している。また，“本装置の稼動による副次的な效果之 しては, 従来行つていなからたスラブの裹面探傷が可能 になつたこと,スラブごとと欠険の有無, 種類, 個数, 位置，分布など各種品質情報が上位計算機に蓄積される ことによつて定量的な品質把握ができるようになつたこ と，さらにリフルタイムで得られた分塊スラブの画像 を製鋼工程のオペレータに迅速にフィードベックするこ とによつて製鋼技術の向上が期待できるようになつたこ となどがあげられる。

\section{7. 考察}

与兄られた画像の中から所望のむのを抽出し，分類す ることは画像処理技術の大きな目的の一つで各種の基本 的な処理法が考えられている. しかし任意の画像に画一 的に適用できる標準的な方法はいまだなく，個々の対象 によつて，その特徽を明確にした上でそれを捕えるアル ゴリズムを，基本的手法を組み合わせたり，搪張したり して，実現しなければならない。ここでは実用上の必要 性からハードゥェアで処理可能な比較的簡単なアルゴリ ズムを考案した．以下にその代表的なるのについての妥 当性を検討する.

\section{1 背量信号の生成}

理想的な背景信号とは，仮に欠陷がないと想定した場 


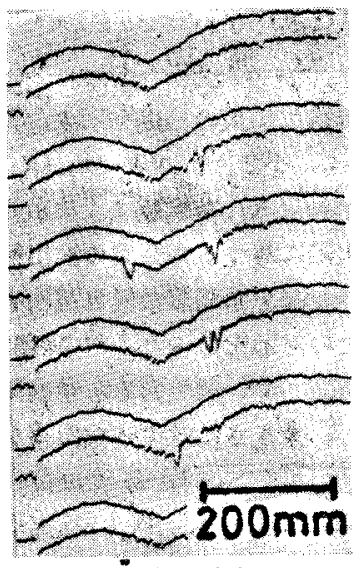

Photo. 3. Vicleo signal and background signal. Upper of each pair is background signal waveform.

合に得られる信号でありこれを実際には久宿がある場 合の映像信号から創り出さねばならない，赤熱スラブに 現れる黒斑には，種々の大きさや濃度のものがありこ れらの画像の空間周波数は背景のそれに近い低域成分を かなり含む．したがつて，単純に従来上く用いられる低 域フィルタや局所平均法などを作用させても、これらの 黒斑を除いた背景信号を創り出すことはできない，そこ で，筆者らは，対象画像から黒斑や煇点を除いた画像を 考えこれを平滑化することにより背景画像を創り出し た. Photo. 3 は, 本装置によつて得られた実際の信号 で，下が側面用㯈像信号，上がその背景信号である。黒 斑の有無に係なく緩やかな材面温度レベルに追従する 信号が得られて扰り，理想的な背景信号が生成されてい る.この方法で用いた $(2)$ 式の条件のをは，生成する背 景信号の材面温度変化に対する追従性を決めるパラメー タとしての意味を持つており，十分大きな值の場合背景 信号は従来の局所平均法と同一のものとなり，十分小さ な值の場合背景信号は全く追従せず一定値となる。その 選定の指針を，映像信号が局所区間で直線的に変化して いる場合に対して検討すると， $\mathrm{g}(i, j)=\hat{f}(i, j)$ であり， 明るさ変化の急峻の程度を表す値 $S(i, j)$ は

$$
\begin{aligned}
S(i, j) & =\hat{f}(i, j)-g(i, j-\Delta n \cdot(N+1)) \\
& =(\hat{f}(i, j)-\hat{f}(i, j-\Delta n)) \cdot(N+1) \\
& =(f(i, j)-f(i, j-1)) \cdot \Delta n(N+1)
\end{aligned}
$$

となる. $f(i, j)-f(i, j-1)$ は, 映像信号の長手方向の 変化率を表しており，明部欠陷のそれを $G_{f}$, 暗部欠宿 のとれを $G_{\mathrm{f}^{\prime}}$ とすると，

$$
\varepsilon_{1}<G_{\mathrm{f}} \cdot \Delta n(N+1), \varepsilon_{2}<-G \mathrm{f}^{\prime} \cdot \Delta n(N+1)
$$

に選べばよいことがわかる．また，大きな欠陥を走査し た後, 背景信号が元の材面レベルにもどる条件として
は， $G_{\mathrm{B}}, G_{\mathrm{B}}{ }^{\prime}$ をそれぞれ明方向, 暗方向への材面温度レ ベルの変化率としたとき; 明部, 暗部の長さをそれぞれ $L, L^{\prime}$ として,

$$
\varepsilon_{1}>G_{\mathrm{s}} \cdot L, \varepsilon_{2}>-G_{\mathrm{s}^{\prime}} \cdot L^{\prime}
$$

である. $G_{\mathrm{s}} \cdot L>G_{\mathrm{f}} \cdot \Delta n(N+1) ，$ まは $G_{\mathrm{s}}{ }^{\prime} L^{\prime}<G_{\mathrm{f}} \cdot \Delta n$ $(N+1)$ になると背景信号が材面温度レベルに追従しな くなる可能性があるが，対象としたスラブでは問題は起 こらず, 本アルゴリズムが背景信号の生成に商当なもの であつたことが確認できた。

\section{2 暗部欠陷における面皘判別}

暗部欠陷桧出に蛙いて，スケールの部分を除去するた め, $8 \times 8$ 画素のテンプレートを 2 回適用する面積判別 法を採用したが，これ以外にも例兄ば個々の斑点に対灾 するカウンタを固き，その部分を走查している間該当す るカウンタに 1 を加光続ける方法もある。しかし 1 走査 線上に現れる斑点の最大個数のカウンタを用意するこの 方法は膨大な個数のスケールの発生があることを考える と適当な方法と言えない１回のテンプレートマッチン グを適用することによつてる面積判別が可能であるが， 1 つの斑点の面積を計算するとき，接近した隣接斑点の 面皘を算入してしまう．そのためには第 1 回目の樎小法 を省くことができないまた小さいテンプレートマッチ ングを繰り返せば，個くの微小斑点の分離は確実に行わ れるが，一方へゲ疪自身が完全な黒斑でなく，部分的に 欠けていることもあり，大形のへゲ症でも消滅してしま う昜合がある.したがつて対象画像の特性に応してテン プレートの大きさ，その適用回数を定めねばならない． 筆者らは種々のモデル画像に対する計算機シミュレーシ ョンと多くの実画像に対する計算機処理を実施し既述の 方法を採用したが，この方法はスヶールの除去に最も妥 当な方法と考えられる.

\section{3 灰色部欠陷の分醀}

灰色部欠陥は既述の上うに信号强度が小さいが有害の 程度は大であり，検出が最る困難なるのであつた。これ の特徵として, 面積と濃度あるいは濃度勾配などる検討 したがハードウェアでリアルタイム処理を容易に行うこ とができることから信号の幅と振幅を用いた 2 次元特徽 空間による抽出法を採用した。これに平面的なつながり 判定を併用した結果所望の欠陌を $\mathbf{S}-\mathbf{N}$ 比よく分離検出 することができたと考えられる。

\section{4 各程欠陷出性能}

Fig. 8 の検出率カーブを見るとへダ疪に関しては約 $\phi 20 \mathrm{~mm}$ のところで急峻に立ち上がつており，設定した 大きさ以上の欠宿はほ㜔出していると言える。これ は, 一ゲ疵の大半が, 輝度变化の大きい暗部欠陥であ 
り，その検出アルゴリズムとして，暗部の 2 值化と面積 判定を用いたことが妥当であつたことを示している．ま た，母材に樑くくい込んだへゲ疵も，灰色部久陷として 精度よく検出していることがうかがえる.

割れについては，検出率カーブの立ち上がり方がゆる やかで，かなり大きな久陷でも見落とす場合があると言 える.しかし，これは，輝度変化のほとんどない割れが あるためであり，多数の材面写真と検出結果の対比で確 認した結果材面写真に現れる割れは，ほとんど明部欠陥， 灰色部欠陥として検出されていることが分かつた．この 装置の欠陷検出アルゴリズムでは，明部欠陥と死色部欠 陥を暗部欠陥と分離検出することができ，ある程度欠陥 の有害性が判断可能と言える．ただ，輝度変化のない久 陥は全く検出することができず，ここに光学的探傷法の 限界がある。

\section{5 ハードウェアによる処理}

多量の情報を高速処理する必要性から，専用ハードウ ェアを構成し, 従来, ほとんど不可能であつた高速のリ アルタイム画像処理を行つた. しかし，あまり複雑なア ルゴリズムを適用することができない，パラメータ以外 の変更が困難であり柔軟性に欠けるなどの欠点も否定で きない，実際の欠陥の見え方は，非常に多様であり，簡 潔に定義できず，学習によつて築かれた人間の欠陷検出 アルゴリズムは，複雑をきわめる．また，欠陷の見え方 は, ホットスカーフの状態に左右される.さらに, 長期 的に見ると, 前工程の技術の進歩によつて出現する欠陷 そのものが変化したり，用途によつても許容水準が変わ る.今後さらに高度な判断機能をもたせるためには, 複 雑で柔軟性のあるアルゴリズムを高速で処理できる画像 処理システムとそのアルゴリズム自身を開発するための ッールの出現が望まれる.

\section{8. 結言}

赤熱状態の分塊スラブの表面疵を検出する光学的探傷 装置を開発した．材面の放射光画像から欠陥の特徵を抽
出して，高速で疵判別を行らため，専用ハードウェアで 構成された高速画像処理を実現した，疵の存在する画像 から疵のない仮想の画像を生成する方法, 明るさや平面 的なパターンから各種欠陥を弁別する方法を考案し，そ のアルゴリズムの妥当性を確認した．特に灰色部欠䧩検 出において, 映像信号波形を特徵づける 2 つのハラメー タによつて作られる 2 次元的な特徵空間の中での領域判 定が有効に利用されることがわかつた，本装置は，現 在, HDR, HCR の際のスラブの品質判定用として有効 に利用されており, 今後, 各欠陥の種類と位置を出力で きることを利用し, 熱間部分疵取りへの適用を検討して いく計画である.

\section{文献}

1 ) 白岩俊男, 厇島龍夫, 坂本隆秀, 久保幸雄, 尾崎 孝三郎，高橋昭夫：鉄と鋼，65 (1979)， S 825

2 ) B. Hedlund: Iron and Steel Inter. (1980) Aug., p. 193

3 ）岩崎全良, 西元善郎, 安国弘晃, 広瀬勇, 林 真司：熱間渦流探傷に関するシンポジウムテキス 卜 (1983), p. 47

4 ）平川紀夫，儀間真一，豊田利夫，松原俊郎：鉄と 鋼, 67 (1981), S 137

5 ) 北川 猛, 藤井 晃, 三宅 䒮, 栗田邦夫：鉄と 鋼, 64 (1978), S 743

6 ）上杉満昭, 山田健夫, 堀内好浩, 吉野正人, 山下 元，小森重喜，宮野治夫：鉄と鋼，67 (1981), $\mathrm{S} 138$

7 ) 田摩兢則, 大橋徹郎，福山 勝，江頭武二：鉄と 鋼, 66 (1980)，S 844

8 ) $B . R$. Suresh, $R . A$. Fundakowski, $T . S$. LevitT and $J$. E. Overland: IEEE Transaction on Patern Analysis and Machine Intelligence, PAMI-5 (1983) 6, p. 563

9) J. L. Mundy: Proceedings IEEE Computer Society International, Computer Software and Applications Conference, Vol. 3 (1979), p. 256

10) L. R. BAKer and B. J. Biddles: Optical Engineering, 15 (1976) 3, p. 244

11) L. Norton Wayne, $W . J$. Hill and $R . A$. Brook: Brit. J. NDT, 19 (1977) Sep., p. 242

12) $A$. Rosenfeld and $A$. C. KAK: Digital Picture Processing (1976), p. 197 [Academic Press] 